So that I am sure you will neither misunderstand me, nor mislike my directness of speech, when I say that, if it please you to believe that the interests of science and of the Royal Society will be advanced by maintaining me in the very distinguished position wlich I at present occupy, I will do my best to justify your confidence; but if, as may well be, you think that some other Fellow of the Society will serve these interests better, I shall, with a light heart, transfer to him the honourable burden, which I have already borne long enough to know its weight.

I now proceed to the presentation of the medals which have this year been awarded by the Council.

The number, the variety, and the importance of Sir William Thomson's contributions to mathematical and experimental physics are matters of common knowledge, and the Fellows of the Society will be more gratified than surprised to hear that the Council have this year awarded him the Copley Medal, the highest honour which it is in their power to bestow.

Sir William Thomson has taken a foremost place among those to whom the remarkable development of the theory of thermodynamies and of electricity in the last forty years is due ; his share in the experimental treatment of these subjects has been no less considerable; while his constructive ability in applying science to practice is manifes'ed by the number of in. struments, bearing his name, which are at present in use in the physical laboratory and in the telegraph office.

Moreover, in propounding his views on the universal di-sipation of energy and on vortex motion and molecular vortices, Sir William Thomson has propounded conceptions which belong to the prima philosophia of physical science, and will assuredly lead the physicist of the future to attempt once more to grapple with those problems concerning the ultimate construction of the material world, which Descartes and Leibnitz attempted to solve, but which have been sedulously ignored by most of their successors.

One Royal Medal has been awarded to Dr. T. Archer Hirst, F.R.S., for his investigations in pure geometry ; and, more particularly, for his researches into the correlation of two planes and into the complexes generated by them.

The other Royal Medal has been awarded to Dr. J. S. Burdon Sanderson, F.R.S., for the eminent services which he has rendered to physiology and pathology ; and, especially, for his researches on the electrical phenomena exhibited by plants, and for his investigations into the relation of minute organisms to disease.

In making this award, the Council desire not merely to recognise the merit of Dr. Burdon Sanderson's researches, especially those on the analogy between the electrical changes which take place in the contractile tissues of plants and those which occur in the like tissues of animals; but to mark their sense of the important influence which Dr. Sanderson has exerted upon the study of physiology and pathology in this country.

The Davy Medal has this year been ayain awarded in dupli cate, the recipient being M. Marcellin Berthelot, Member of the Institute of France, and Foreign Member of the Royal Society, and Prof. Julius Thomsen, of Copenhagen.

The thermo-chemical researches of Berthelot and Thomsen have extended over many years, and have involved an immense amount of work, partly in the application of established methods to new cases, partly in devising new methods and applying them to cases in which the older methods were not applicable. Chemists bad identified a vast variety of substances, and had determined the exact composition of nearly all of them, but of the forces which held together the elements of each compound they knew but little. It was known that certain elements combine with one another with great evolution of heat-forming products in which they are firmly united; while other elements combine but feebly, and with little evolution of heat. But the materials for forming any general theory of the forces of chemical combination were but scanty and imperfect.

The labours of Messrs. Berthelct and Thomsen have done much towards supplying that want, and they will be of the utmost value for the advancement of chemical science.

\section{THE JAVA DISASTER}

THE following letter from the Liverpool Daily Fost, received from Capt. W. J. Watson, of the British ship Charles Bal, contains a graphic and interesting account of the recent terrible volcanic outburst in Sunda Straits. Capt. W. J. Watson was himself an eye-witness of what he describes. His vessel was actually within the Straits, and not far from Krakatoa when that island had become an active volcano:-

"August 22, $15^{\circ} 30^{\prime}$ S., 105 ${ }^{\circ}$ E.-About 7 p.m. the sea suddenly assumed a milky-white appearance, beginning to the east of us, but soon spreading all round, and lasting till $8 \mathrm{p.m}$. There were some clouds (cumulus) in the sky, but many stars shone, and in the east to north-east a strong, white haze or silvery glare. This occurred again between 9 and ro p.m., the clouds also appearing to be edged with a pinkish coloured light, the whole sky also seeming to have extra light in it, similar to when the aurora is showing faintly. On the 24 th, in $9^{\circ} 30^{\prime} \mathrm{S}$. $105^{\circ} \mathrm{E}$, we had a repetition of the above. On the night of the $25^{\text {th }}$, standing in for Java Head, the land was covered with thick, dark clouds and heavy lightning. On the 26th, about 9 a.m., passed Prince's Island, wind south-west, and some heavy rain; at noon, wind west-south-west, weather fine, the Island of Krakatoa to the north-east of us, but only a smiall portion of the north-east point, close to the water, showing; rest of the island covered with a dense black cloud. At 2.30 p.m. noticed some agitation about the Point of Krakatoa; clouds or something being propelled from the north-east point with great velocity. At 3.30 we heard above us and about the island a strange sound as of a mighty, crackling fire, or the discharge of heavy artillery at second intervals of time. At 4 I 5 p.m., Krakatoa north half east, ten miles distant, observed a repetition of that noted at 2.30 , only much more furious and alarming, the matter, whatever it was, being propelled with amazing velocity to the north-east. To us it looked like blinding rain, and had the appearance of a furious squall of ashen hue. At once shortened sail to topsails and foresail. At five the roaring noive continuta and increased; wind moderate from south south-west; darkness spread over the sky, and a hail of pumice-stone fell on us, many pieces being of considerable size and quite warm. Had to cover up the skylights to save the glass, while feet and head had to be protected with boots and southwesters About six o'clock the fall of larger stones ceased, but there continued a steady fall of a smaller kind, most blinding to the eyes, and covering the decks to three or four inches very speedily, while an intense blackness covered the sky and land and sea. Sailed on our course until we got what we thought was a sight of Fourth Point Light; then brought ship to the wind, south-west, as we could not sec any distance, and we knew not what might be in the Straits, the night being a fearful one. The blinding fall of sand and stones, the intense blackness above and around us, broken only by the incessant glare of varied kinds of lightning and the continued explosive roars of Krakatoa, made our situation a truly awful one. At I I p.m., having stood oft from the Java shore, wind strong from the south-west, the island, west-north-west, eleven miles distant, became more visible, chains of fire appearing to ascend and descend between the sky and it, while on the south west end there seemed to be a continued roll of balls of white fire; the wind, though strong, was hot and choking, sulphureous, with a smell as of burning cinders, some of the pieces falling on $\mathrm{u}$; being like iron cinders, and the lead from a bottom of thitty fathoms came up quite warm. From midnight to 4 a.m. (27th) wind strong, but very unsteady, between sou'h-south-west and west-south-west, the same impenetrable darkness continuing, the roaring of Krakatoa less continuous, but more explosive in sound, the sky one second intense blackness and the next a blaze of fire, mastheads and yardarms studded with corpo ants and a peculiar pinky flame coming from clouds which seemed to touch the mastheads and yardarms. At 6 a.m, being able to make out the Java shore, set sail, passing Fourth Point Lighthouse at 8 ; hoisted our signal letters, but got no answer. Passed Anjer at 8.30, name still hoisted, close enough in to make out the houses, but could see no movement of any lind; in fact, through the whole Straits we have not seen a single moving thing of any kind on sea or land. At $10.15 \mathrm{a} . \mathrm{m}$. passed the Button Island onehalf to three-quarters of a mile off; sea like glass round it, weather much finer looking, and no ash or cinders falling; wind at south-east, light. At 11.15 there was a fearful explosion in the direction of Krakatoa, now over thirty miles distant. We saw a wave rush right on to the Button Island, apparently sweeping right over the south part, and rising half way up the north and east sides. This we saw repeated twice, but the helmsman says he saw it once before we looked. The same wave seemed also to run right on to the Java shore. At the same time the sky rapidly covered in ; the wind came strong 
from south-west by south; by II. 30 ne were inclosed in a darkness that might almost be felt, and at the same time commenced a downpour of mud, sand, and I know not what; ship going north-east by north, seven knots per hour under three lower topsails; put out the side-lights, placed two men on the look-out forward, while mate and second mate looked out on either quarter, and one man employel washing the mud off binnacle glass. We had seen two vessels to the north and north-west of us before the sky closed in, adding much to the anxiety of our position. At no on the darkness was so intense that we had to grope our way about the decks, and although speaking to each other on the poop, yet could not see each other. This horrible state and downpour of mud, \&c., continued until I.30, the roarings of the volcano and lightnings being s mething fearful. By 2 p.m. we could see some of the yards aloft, and the fall of mud ceased. By 5 p.m. the horizon showed out in the north and north-east, and we saw West Island bearing east and north, just visible. Up to midnight the sky hung dark and heavy, a little sand falling at times, the roaring of the volcan , very distinct, although in sight of the North Watcher, and fully sixtyfive or seventy miles off it. Such darkne-s and time of it in greneral few would conceive, and many, I dare say, would disbelieve. The ship, from truck to water-line, is as if cemented; spars, sails, blocks, and ropes in a terrible mess; but, thank God, nobody hurt or ship damaged. On the other hand, how fares it with Anjer, Merak, and other little villages on the Java coast ?"

\section{UNIVERSITY AND EDUCATIUNAL INTELLIGENCE}

OXFORD.-The Natural Science Scholarships at Christ Church have been awarded after examination to Mr. R. E. Seholefield, of Leeds Grammar Scho 1, and Mr. H. Bankes Price, of Christ's College, Brecon. The Brakenbury Natural Science Scholarship at Balliol College has been awarded to $\mathrm{Mr}$. R. P. Baker, of Clifton College. The following gentlemen were distinguished in the examination:-Mr. W. H. Littleton, Royal School of Mines, Mr. T. H. J. Watts, of Llandovery School, and Mr. C. E. Rice, of Derby Grammar Sch.ool.

An examination will be held on Janu rry 29 at Queen's College for the election of a scholar in Natural Science.

CAMbridge. - The Special Board for Mathematics, in publishing, after the lapse of two-thirds of the present term, a lis of professorial lectures on Mathematics, with a list of College lectures open to all members of the University, states that six associated Colleges, Peterhouse, Pembroke, Corpus, Queens', St. Catharine's, and Downing, provide no lectures on higher Mathematics this term, while none will be given during the year at Jesus, Trinity Hall, Magdalen, Sidney, Cavendish, and Selwyn. St. John's does not as yet open any of its adva: ced lectures to other than its own students. Trimity, on the con trary, has five advanced courses this term open to the Univer-ity, viz. Mr. Thomson on Electrostatics and on Statics and Attractions, Mr. Ball on Higher Differential and Integral Calculus, Mr. Glazebrook on Geometrical Optics, and Mr. Glaisher on Elliptic Functions. At King's Mr. Stearn is lecturing on Electrostatics, at Christ's Mr. Hobson on Magnetism, at Clare Mr. Mollison on Fourier's Theory and Heat. Several subjects in higher Mathematics are unrepresented by lectures this year, such as Differential Equations, Calculus of Finite Differences, Calculus of Variations, Theory of Prohability, Lagrange's and Bessel's Functio «, Higher Dyna nics, Newton's “Principia," Planetary Theory, and Precession. The Board regret that no conference of mathematical lecturers has been beld, and that there is no uniformity of procedure between the different Colleges. In all the other chief departments of study, programmes of advanced lectures for the whole year were published last June. It is somewhat of a reproach to Cambridge mathematicians that no such list is published in regard to what was once so distinctively the characteristic study of Cambridge.

The following are the examiners for the Natural Sciences Tripos of 1884 :- Prof. A. M. Marshall (zoology), Dr. F. Darwin (botany), Mr. Langley (physiology), Dr. R. D. Roberts (geology), Mr. L. Fletcher (mineralogy), Mr. W. N. Shaw (physics), Mr. A. Hill (human anatomy), Mr. Pattison Muir (chemistry).

The recommendations of the General Board of Studies as to the Professor of Pathology, new readers, University lecturers, demonstrators, grants for apparatus, \&c., will be voted on December 6 at noon.

Prof. Foster has heen appointed on the University Librar Syndicate; Prof. Foster and Dr. Vines, the Butanic Garden Syndicate; Revs. Coutts Trotter and E. Hill, the Museums and Lecture Rooms Syndicate ; Messrs. H. Darwin and J. J. Thomson, the Observatory Syndicate; Prof. Cayley, the University Press Syndicate; Dr. Gaskell and Mr. A. S. Lea, the Oxford and Cambridge Examinations Syndicate ; Prof. Foster, the State Medicine Syndicate; Prof. Stuart and Mr. J. Ward, the Teachers' Training Syndicate.

The following appointments on Special Boards bave been made :-Mr. A. S. Lea (medicine), Dr. Ferrers (mathematics), Prof. Stokes (physics and chemistry), Mr. J. E. Marr (biology and geology).

Prof. Macalister has been appointed Examiner in the 2nd M.B. in place of the late Mr. James Shuter.

Mr. W. Gardiner of Clare College has been approved as a Teacher of Botany for the purposes of medical study.

\section{SCIENTIFIC SERIALS}

THE Gournal of Anatomy and Physiology, vol. xviii. part I, October, 1883 , contains :-On the development of the suspen sory ligament of the fetlock in the foetal horse, ox, roe deer, and sambar deer, by Prof. Dr. J. Cunningham, M.D. (plate I). -On the action of infused beverages on peptic digestion, by Dr. J. W. Frazer (plate 2). - On a method of promoting maceration for anatomical museums by artificial temperature, by Prof. Struthers, M.D.-On the wax-like di ease of the heart, by Prof. D. J. Hamilton, M.D. (plate 3).--On the relations of the dorsal artery of the foot to the cuneiform bones, by A. Hensman.Researches into the histology of the central gray substance of the spinal cord and medulla oblongata, by Dr. W. Ainslie Hollis, part 2 (plate 4). - On some points in the anatomy of the chimpanzee, by J. B. Sutton.-Observations upon the osteology of Podasocys montanus, by Dr. R. W. Shufeldt (plate 5).--Shor notes on the myology of the American black bear, by Prof. F. J. Shepherd, M.D.-Total absence of the left lobe of the thyroid body, by Dr. W. J. Gow.-Note respecting the course of the flexor longus digitorum pedis, by Dr. Sinclair White.-On the os centrale in the human carpus, by Prof. W. Gruber.

The Quarterly Fournal of Microscopical Science for October, I 883 , contains :- Observations on the genus. Pythium, by $\mathrm{H}$ Marshall Ward, M.A. (plates 34 to 36).- -On budding in Polyzoa, by Prof. A. C. Haddon, M.A. (plates 37,38 ). - On the structure and relations of Tubip ra, by Sydney J. Hickson, B.A., B.Sc. (plates 39,40 ).-On the malleus of the Lacertilia and the malar and quadrate bones of the mammalia, by $\mathrm{M}$. $\mathrm{L}$. Dollo (plate 4I).-Notes on Echin derm morphology, No. 6; on the anatomical relations of the water-vascular system, by $\mathrm{P}$. Herbert Carpenter, M.A.-Recent researches upon the origin of the sexual cells in hydroids, review by A. G. Bourne, B. 'c.On the osteology and development of Syngnathus peckianus (Storer), by J. Playfair McMurrich, M.A. (plates 42, 43).

THE American Fournal of Science, November, 1883. - Results of some months' examination of the spectra of sunspots with an instrument of high dispersion, by Prof. C. A. Young.-On thie meteoric iron mass found by F. M. Anderson near Dalton, Whitfield County, Georgia, in 1879 (two illustrations), by Charles Upham Shepard, sen. The analysis gave iron $94^{\circ} 66$, nickel 4.80 , cobalt $0^{*} 34$, with traces of phosphorus, chromium, and manganese. - Notice of some varieties of corundum recently found at Sungchang, Zanskar district, Western Himalayas, by the same author.-Phenomena of the Glacial and Champlain periods about the mouth of the Connecticut Valler, that is, in the New Haven region (two maps), by James D, Dana. The author concludes that two simultaneous movements existed in the glacier ice-a lower along the valley, an upper crossing it obliquely; that both transported drift material, and that on reaching Long Island Sound the lower changed its own direction of flow for that of the general glacier mass across the Sound and I.ong Island.- On a variety of descloizite from Zacatecas, Mexico, by Samuel L. Penfield.-On Hybocrinus, Hoplocrinus, and Bærocrinus (two illustrations), by Charles Wachsmuth and Frank Springer. - Note on Mr. Nipher's papers on the evolution of the American trotting horse (one illustration), by W. H. Pickering. The author holds that we may foretell the speed attained for a few years in advance, but not the 